\title{
THE VANISHING SACRED GROVES ("KAVUS") IN THE 'GOD'S OWN COUNTRY' AND ITS ECOLOGICAL SIGNIFICANCE
}

\author{
Umesh U*, Ms. Sheena **
}

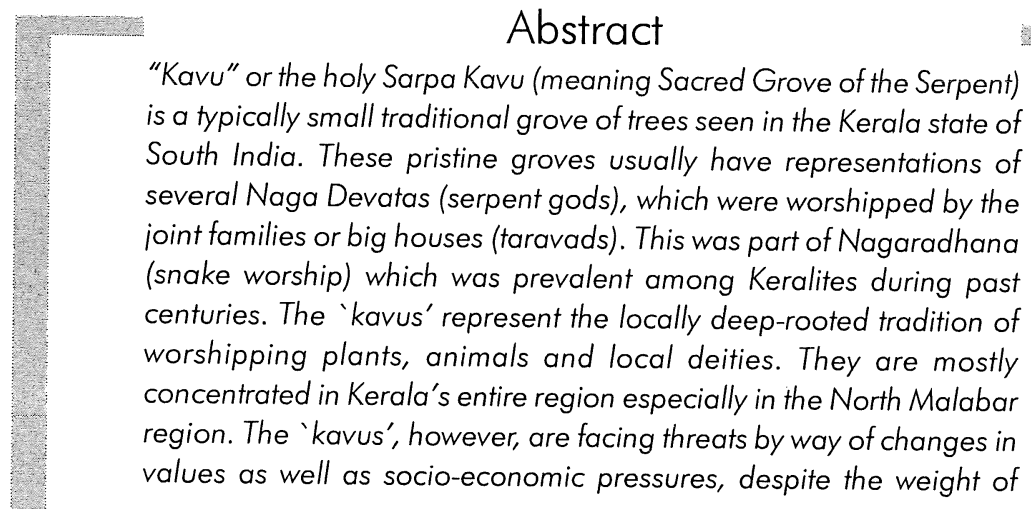

* College of Applied Science, Puthenvelikara P.O., North Paravur, Ernakulam district. Kerala.

** Department of Commerce, School of Management, Pondicherry University, Karaikal -609605. 
traditional beliefs and rituals associated with them. Large scale conversion of land, decline of traditional agrarian values, socioeconomic factors, population pressure and shortage of land have already made a dent on the rich ecosystem of 'kavus'. A large number of 'sarpa kavus', that were protected and maintained by upper caste communities, disappeared, due to the disintegration of families that protected them. In some cases, this led to their renovation and conversion into temples. There are reports stating that the 'kavus' suffered large scale degradation in the state due to high percentage of settler migration. These rich ecological repositories that also function as traditional water-harvesting system are not being given due importance. Most of the 'kavus' are located near agricultural lands; this indicates their role in an agrarian society. Most of the 'kavus' have perennial water resources rich in organic matter that enhance fertility of agriculture lands. Community protection alone can save the 'kavus'. Only through solid initiatives, it's possible to create awareness about 'kavus' ecological value among the communities (stakeholders); traditionally protecting the 'kavus' and the public. Sanctity of the 'kavus' may have been sustained by beliefs. No less important is their protection by highlighting their ecological importance.

\section{Introduction}

The concept of sacred groves in India has its roots in ancient times. Ramakrishnan (1997) traces its antiquity to the pre-Vedic period. He argues that, "Vedic people assimilated new environmental values and the concept of 'sacred groves' from the value system of the original inhabitants of the Indian subcontinent" and that it became a widespread practice. In the post-Vedic period, in addition to considering a landscape as such valuable and sacred, individual species and micro units also began to be treated as sacred. It may be assumed that traditional Hindu society recognised individual species as objects of worship, based on accumulated ancient knowledge and their identified value for specific use. Some species are employed in religious ceremonies as part of socio-cultural traditions.

\section{Sacred landscape}

Instead of a patch of virgin vegetation, people sometimes used to consider an entire landscape as sacred and used to worship it. The reason may be the belief that such a conception of the landscape will make certain the persistence of their cultural practices and also ensure the sustainability of the landscape. The course of 
the sacred river Ganga is cited as an example of sacred landscape. The Sabarimala enclave (Lord Ayyappa) and the hill of Kunnathurpadi where Muthappan (Lord) is worshiped once in a year are illustrations of sacred landscapes from Kerala. The local communities consider many mid-land hills around their locality as sacred landscapes. But present researchers are of the opinion that any attempt to link the concept of sacred landscape with the notion of sustainability requires further exploration both conceptually and empirically, especially if one wants to develop it as a conservation tool.

\section{The concept of sacred groves}

Sacred lands are found everywhere around the world. In all parts of Africa, various tribes consider different types of groves as sacred. In West Asia, Babylonians and Assyrians had planted sacred groves. Palm forest with altar has been reported from Arabia. Sacred Oak grove was present in Asia Minor. Sacred mountains and lakes are present in Madagascar.

Many Siberian people honoured sacred groves. Village groves are present in Korea. In Japan, Shinto shrines, as a rule are surrounded by trees. Buddhist temples in Japan and China have tree-gardens. The traditional Chinese honour sacred mountains with trees, the Buddhist monasteries and temples of Thailand have sacred groves and Indonesia has monkey-forests. Sacred groves were also present in Greece, Italy, France, Scandinavia, Sweden, Finland, British Islands, Arctic Russia, New Zealand, and Polynesia. Sacred groves are present in Nepal and Sri Lanka. In America, both pre-Columbian people and the settlers maintained sacred groves.

In India sacred groves are found in a wide range of ecological situations from estuaries to mountain localities. Gadgil and Vartak (1976) record that the important regions with sacred groves in India are the North Eastern Himalayas (Khasi-Garo hills), Western Ghats, Aravalli Hills of Rajasthan and Sarguja, Chandes and Bastar area in Central India. But this does not include the coastal and mid-land regions of Kerala where sacred groves are abundant. In Kerala sacred groves are widely distributed from the West Coast to the Eastern high lands. They are known by various names as Kavu, Sarpakkavu, Nagam, Mundya, Vallikkettu, etc.

The following table lists the names of the various sacred groves and the places where they are found in India: 
Table 1: The various terminologies for sacred groves in different regions of India

\begin{tabular}{|l|l|}
\hline Terminology & Region \\
\hline 'Dev' & Madhya Pradesh \\
'Sarnas' & Maharashtra \\
'Jankor' & Munda tribes of Jharkand \\
'Jaher' & Munda tribes of Jharkand \\
'Pengenda' & Santal tribes of Jharkand \\
'Oran' & Gonds tribes of Jharkand \\
'Jogmaya' & Vanis, Kenkris, and Shamlet Dehs tribes of Rajasthan \\
'Deorali' & Rajasthan \\
'Lakyntang' & Darieeling \\
'Sidharavana' & Meghalaya \\
'Devarakadu' & Karnataka \\
'Pavithravana' & Karnataka \\
Kavu & Karnataka \\
Sarpakkavu & Kerala and Tamil Nadu \\
'Nagam' & Kerala and Tamil Nadu \\
'Mundya' & Kerala and Tamil Nadu \\
'Vallikkettu' & North Kerala \\
\hline
\end{tabular}

The practice of keeping sacred groves was prevalent among different communities depending on their cultural practices. Tradition in the study area of preserving a patch of wilderness as sacred had been interpreted differently by various scholars. Gadgil and Vartak, (1976) record Western Ghats as one of the important regions with sacred groves. This includes only the highlands of Kerala. Even though there is lack of clarity in mentioning the region, they do not consider sacred groves as relatively unimportant in Kerala. According to Chandran, Hughes and Gadgil, (1997) the history of sacred groves in Kerala may be traced back to the hunting gathering societies which attributed sacred value to patches of forest within their territories, similar to the way they treated several other topographic or landscape features like the mountain peaks, rocks, caves, springs, and rivers. 
According to Ramachandran and Mohanan (1991), Hindus in Kerala set aside a portion of land around the house as abode of God, Goddess or Serpent and this was also a means for preserving medicinal plants. They attribute the origin of sacred groves to more secular causes, for the preservation of rare and valuable plants. They hold that the practice started well before sixth century AD. It is inferred that the practice of setting aside patches of forests as sacred groves was strengthened with the spread of shifting cultivation involving clearing of forests. The reason for this could be religious and cultural compulsions as well as subsistence and ecological needs.

Historical evidence shows that the human habitation in Kerala especially in the Malabar region started about five thousand years ago. Even though the Brahmin migration to this region began in the early centuries of Christian era, well organised Brahmin settlements began to appear only by the $7-8^{\text {th }}$ century AD. One of the consequences of the Brahmin settlements was the spread of settled agriculture especially in the costal plains and the midland, leading to deforestation in these regions.

Introduction of the commercial plantations in the highland by the British invariably resulted in the destruction of the highland forests and its fauna. Initially highland cultivation was restricted to the areas with less incline such as Wayanad. But later a major part of the highland forests of Kerala has been cleared for cultivation of tea, coffee, cardamom and other cash crops. In spite of the massive destruction of forest elsewhere, there were patches of forests in Kerala set aside in the form of sacred groves.

Sacred groves are patches of natural vegetation surviving in the man-modified landscapes. They owe their preservation to their perceived importance to some form of divinity. Hughes and Subhash Chandran (1997) define 'sacred groves' as segments of landscape containing trees and other forms of life and geographical features, that are delimited and protected by human societies believing that preserving such a patch of vegetation in a relatively undisturbed state is necessary for expressing one's relation to the divine or to nature. So these remain as isolated patches of forests in the midst of agricultural landscapes. Sacred groves are often the only lingering samples of natural vegetation in the man-modified landscapes of Kerala. In most localities, sacred groves are being increasingly exposed to various kinds of threats leading to either qualitative degradation or total disappearance.

This paper aims to throw light on the urgent need for conservation of sacred groves by generating a crucial baseline data on these neglected repositories of biodiversity in Kerala. It highlights the ecological importance of sacred groves. It analyses the 
social conditions essential for ensuring long-term conservation of sacred groves i.e., the social sustainability factor. The previous studies provide information projecting some aspects of the richness of the sacred groves in this area. They do not, however, highlight all the aspects which would necessitate social preservation of the groves. Structured information is lacking.

Hence this study is an attempt to build a database on social preservation, to stress on the importance of groves as refugia and as biodiversity inocula, to describe the ecological and cultural services provided by the groves and to explain the socioeconomic aspects of degradation of groves.

\section{Review of literature}

Freeman (1999) states, the transformation of land use pattern initiated by a single generation of settlers cleared nearly all the natural forest cover of the region and converted the former jungle land into cultivated field of rubber, pepper, areca, tapioca, coconut and cashew. Consequence of all these are snuffing out the ecologically attuned way of life of the early inhabitants of ecological balance.

Unnikrishnan $(1990,1995)$ conducted a preliminary survey of the sacred groves. He has documented more than 32 species of plants that are endemic to the Western Ghats. Wild relatives of a number of cultivars were also reported from the sacred groves. The figures are more astounding when it comes to the faunal diversity. Among the 90 species of birds documented, 10 were endemic to the Western Ghats; 34 species of birds were found breeding in the sacred groves. More interesting is the fact that 40 species of birds, which are typical forest species and had found the sacred groves to be equally habitable. More than 20 species of birds are reportedly migrants.

\section{Sacred groves as centres of biodiversity}

The prime concern of any society is to ensure constant supply of raw materials and resources to its members. At present our natural resource base is degrading, depleting or degenerating due to wanton exploitation. This undermines the very sustenance of the society.

This generalisation is especially true in the case of genetic resources, one of the most powerful and strategically important raw materials of the present day society. As biotechnology expands its reach to include the domains of agriculture, medicine and industrial production, the search for new genetic materials to suit the emerging 
needs is intense. Most genetic engineering at present hardly goes beyond discovery and patenting of the use and the denial of use rights. Need for long-term conservation of raw materials and the necessity to permit the continuity of organic evolution, which produces that genetic material and are easily overlooked. This is especially true in the case of tropical countries, most of which faced with the choice between short-term economic growth and long-term resource conservation, are confused.

Biological diversity or biodiversity, as the term is commonly used, is the sum total of life forms at all levels of organisation in the biological system. The term biodiversity has been defined by scholars in many ways. One of the internationally accepted definitions is given by the Convention on Biological Diversity (CBD). Article 2 of the $\mathrm{CBD}$ defines Biological diversity as the variability among living organisms from all sources including inter alia, terrestrial, marine, and other aquatic ecosystems and the ecological complexes of which they are part. This definition includes biological diversity within species and of ecosystem. Biodiversity is the totality of life-forms from where we directly or indirectly draw ecological, economic, and aesthetic benefits. The entire biosphere forms a macro ecosystem and biodiversity offers the buffering capacity and sustainability to life on the planet. As more and more natural vegetation is lost in the inhabited areas, the remaining patches of forests in the form of sacred groves come to acquire a crucial role in buffering biodiversity. Thus sacred groves acquire importance from the point of view of ecology and conservation of biological diversity.

The most tangible evidence of the deterioration of biodiversity is seen in the tropical vegetation. The forests are fast disappearing, threatening the very existence of a major portion of global biodiversity and also challenging the very process of organic evolution. All the human beings have to currently look for existing remnants of climax communities (Climax community is the one which has attained a steady state after a long period of ecological recession. It is a stable biotic community) for the sustenance of genetic diversity. In spite of the widespread destruction of forests, there are still left aside certain natural landscapes in various countries which are culturally protected as sites of worship by local people. What remains after destruction and offer refugia for species.

Such refugia, even though fragmented, may be maintaining the minimum viable population of some species and are thus capable of maintaining part of the biodiversity. All over the world, in the course of human history, some such isolated patches of natural vegetation which remain in spite of the wanton destruction of large stretches of forests have been protected by clothing them with sacredness. At present, they are known as sacred groves. In a way, Indians especially the Keralites are undoubtedly indebted to the cultural practices of their ancestors for maintaining such refugia. 
Cultural practices always have their impact on environment. They determine the community use (and abuse) of natural resources. They modify the fragile ecological balance and diversity of our plant and animal life, and sometimes destroy it and leading to the loss of biota. Cultures in turn are shaped by the environment. Climate and natural resources condition the ways of life of a population influence the nature and scope of its interactions with other human groups and also inspire its artistic expression. Since the birth of humanity, populations have derived from nature, aesthetic or spiritual sustenance and used it to creative ends.

The multiple aspects of culture and environment are reflected in activities of a number of UNESCO programmes. Examples include studies within 'The Man and Biosphere Programme' on the role of sacred groves in the conservation of biodiversity and the rehabilitation of degraded lands, the promotion of ethno botany and the sustainable and equitable use of plant resources. This paper is an attempt to provide additional glimpses into some of these multiple dimensions of culture and environment including the role of religious sanctuaries and sacred places in contributing to the conservation of biological diversity.

\section{Objectives}

- To make the term "sacred groves" more vibrant \& important in the current, gadgets oriented fast life, where 'global warming' threat is the main villain along with terrorism, extremism, and malnourishment for all the living beings of this planet.

- To list the external influences leading to the degradation of sacred groves.

- To identify the reasons for the change in attitude if any of the individual or community towards sacred groves.

- To propose an integrated scheme for conservation of the sacred groves as an asset of the community i.e. by ensuring social preservation in the long run.

\section{Methodology}

1. Preliminary survey for collecting data on various aspects was done through unstructured interview from the respective locality.

2. Oral history from elder generation was collected.

3. Data from stakeholders of various statuses were collected by means of unstructured interviews and informal conversations. 
4. Secondary data from websites, journals, different articles in this area, prior works undergone in this field were searched and scrutinized to get a proper vision about this issue.

\section{Sacred Groves: The abode of serenity and adulation}

The sacred groves are of three types: Daivakkavu, where a male God is worshipped, Bhagavathikkavu, where a female God is worshipped, and Nagam or Sarpakkavu, where snakes are worshipped. Nagam or snake groves are numerous. Many of them are of small size. Yet large snake groves like Edayilekkadu exist in the state. Sacred groves are present throughout Kerala. In Kannur and Kasargod districts their distribution extends from West Coast to the foothills of Western Ghats. They exist as holy places for worshiping Gods, Goddesses, and Serpents. Many of them have small shrines attached to them. Thick climax vegetation persists in many sacred groves, whereas in some others it is degraded; in still others, the entire vegetation has been cleared leaving only the shrine. Complex rituals are performed in almost all of these groves which include periodical performance of Theyyam, a practice of worshiping Gods and Goddesses in north Malabar. Each shrine, which stands in the name of a Theyyam, was associated with a sacred grove or situated within a sacred grove. But in many at present the vegetation has been destroyed and only the shrine exists. Another remarkable feature is the large size of the sacred groves in this area, when compared with those of south Kerala.

In Kasargod and northern part of Kannur district Kavu means sacred forest. The word Nagam is generally used here to denote a serpent grove. Shrines are present in association with many sacred groves of Gods and Goddesses. But some of them have only a small holy place in the form of a stone, idol, platform or a single tree for worship. In serpent groves usually there is no shrine inside or outside. Some idols or stones represent the place of serpent god. The term Mundya is also used for sacred forest of God worship. At present in many cases Kavus or Mundyas have turned to be simply shrines since the associated forest has been destroyed in the name of development. Sacred groves are abundant in Kannur district.

The study of Ramachandran and Mohanan (1991) showed the presence of largest number of sacred groves in Alappuzha district where there were 65 sacred groves. Iringol kavu of Ernakulam district was the largest Kavu in their findings. It had the size of 20.23 hectares and was the only grove of more than five hectares in the southern districts. Sacred groves in the study area ranges from very small (about one cent) to 24.282 hectares. If Kottiyoor sacred forest is given the status of sacred grove, the size reaches 36.423 hectares. 
The sacred forests of this region are ecologically better preserved. The forest type is mostly of wet evergreen. A few have drier types ranging from semi evergreen to deciduous. All maintain fertility of soil and purity and humidity of air in the surroundings. The neighbouring lands get water from them. They are centres of village biodiversity.

Many of the sacred groves are now private property forming part of home gardens. Others are in community properties of a cluster of related families. Still others exist as common property of the village community. Many of the groves attached to homesteads have been destroyed.

\section{Ecological significance of sacred groves}

From time immemorial the sacred groves in India have been the focus and symbol of a way of life. In such groves the highest levels of biological diversity are still found; there humans interact with nature (Marglin and Mishra, 1933, as cited by Hughes, 1998). According to Ramakrishnan (1996) ecologically valuable species function as keystone species in an ecosystem and contribute to the enhancement of biodiversity. They are also species that are socially valued by the local village communities for cultural and religious reasons. Specific rules regarding usage of sacred groves varied from place to place and from time to time. The usual attitude concerning sacred groves was that nothing in normal circumstances ought to be broken, killed or removed from there. However, certain limited forms of use such as gathering for medicinal purposes were sometimes permitted. Those regulations became effective in providing refugia for species that otherwise would have disappeared from the ecosystem. Herbs like Nervilia sp. of Edayilekkadu and tree species like Myristica fatua of Paliyerikkavu are cases in point. Best examples for animal species are Presbytis johni (Nilgiri langur), Loris tardigradus (slender loris) and Manis pentadactyla (Pangolin) of Thavidisserikkavu and spizaetus cirrhatus cirrhatus (white bellied sea eagle) of coastal groves like Edayilekkadu. Kammadath kavu maintains a microclimate similar to that of the rainforest and it harbours a species of tree fern, Cyathium. Normally there would be loss of species due to the small size of many groves but the remnants would still be of great importance from the point of view of landscape ecology.

The sacred groves of Kerala are relics of wet evergreen forests. The guard they obtain on spiritual grounds help them to survive (Unnikrishnan, 1990; Ramachandran and Mohanan, 1991). It has been exposed that each grove is maintaining a microclimate with rich biodiversity. The selected groves show the existence of many species of medicinal plants. The rare endemic elements of the 
Western Ghats are fairly well preserved in Kavus. Balakrishnan and Induchoodan (1996) compare the floral diversity of rain forest with sacred groves. According to them, nearly 960 species of angiosperms are present in the $90 \mathrm{sq} . \mathrm{km}$ in Silent Valley whereas sacred groves contain 722 species per $1.4 \mathrm{sq} . \mathrm{km}$. This may not be the right way of comparing diversity because the kavus are widely dispersed within a greater geographical area. Yet it indicates the species richness in kavus.

A variety of species of animals are found in the sacred groves. They spill over the borders and are found outside if there are treecover. There are regional differences in the fauna. Lowland sacred groves have typical wetland birds and other common animal forms. Lower mid-land sacred groves are also having similar faunal composition. The fauna of the higher midland and highland sacred groves are typical of rainforests.

General observations on the fauna of various sacred groves were recorded in our survey. The most prominent groups of animals inhabiting sacred groves were observed and the species listed in order to assess the richness of the faunal diversity. Groups observed and listed under non-chordates included butterflies and spiders and those under chordates included Amphibia, Reptilia, Aves and Mammalia.

A proposal prepared by the Divisional Forest Office says that more than 50 species of life forms reported from the 'kavus' in the region are endemic to the Western Ghats. A plant, Sysysium Travancuricium, which was considered extinct, has been found in the Andalur kavu, near Thalassery. There are more than 200 medicinal plants found in the 'kavus'.

The role of sacred groves as refugia becomes evident from the abundance of varied groups of animals in these forest patches; 117 species of butterflies, 8 species of spiders, 11 species of amphibians, 23 species of reptiles, 178 species of birds and 24 species of mammals were identified from the sacred groves in the various localities in the State. Of these, 10 belong to Schedule-l in Wildlife (Protection) Act 1972.

It is exciting to note that faunal elements that have evolved through millions of years are preserved in these small, isolated pockets of forests. The undisturbed sacred forests retain such typical forest forms otherwise found only in the more extensive parts of the Western Ghats. For instance, Thavidisserikkavu, a prominent mid-land grove of Peringome panchayat is said to be having a rare, endangered primate and Presbytis jhonii (Nilgiri langur). 


\section{Ecosystem services}

Sacred groves deliver a number of ecosystem services. The benefit conferred, when compared with their small size, is relatively greater. Generally kavus provide a variety of ecological services such as:

1. Kavus are isolated patches of evergreen forests. As a biological resource, each kavu has its individuality. Rare species of plants exist in them. The animals depending on them also find kavus as refugia.

2. Plants in the groves increase the quantity of oxygen in the village atmosphere. Transpiration will increase humidity in the immediate vicinity and provide a more favourable microclimate for many organisms. The humidity and the cool atmosphere are blessings for the local residents. Plants absorb dust. Hence the grove acts as the lung of the village where it's present.

3. Kavu prevents the spreading of desiccation and reduces the incidence and intensity of fire, at least in some terrains as in the midland laterite beds in the region.

4. Forests form the main watershed areas. Groves are as good as rain forests in storing ground water and are providing more dependable sources of water for the organisms inside as well as in the neighbourhood. Almost all sacred groves contain water in the form of groundwater, springs, pools, lakes or streams. The vegetation enables replenishment of groundwater resources. Rivers originating in the midland in this region are perennial partly owing to the sacred groves. For instance, Arvanchal stream originating from Aravanchal kavu after receiving springs from Thavidisserikkavu joins Peruvamba River. Paddy fields near Paliyerikkavu, Kammadath kavu, Thavidisseri kavu Edayilakkadu etc., get sufficient water from the groves. Groves are also helpful in sustaining freshwater springs that empty into water bodies situated near salt water. Another example: the well inside the sacred mangrove of Thazhekkavu (Thekkumbad, Mattool) contains freshwater in spite of the fact that it is adjacent to salty water and is illustrative.

5. Fertility of the soil in the surrounding area of groves is increased by the humus from them. During monsoon season these organic matters even reach the coastal sea to sustain fish fauna. When litter accumulates, organic materials build the soil and are returned to the biomass of the standing forest. In this process, many micro-organisms, invertebrates, fungi etc., will flourish and many species not found in the ploughed fields and secondary forests are present in the groves. 
6. There are many species, such as Adapathiyan, Ilippa, Eenthal, which directly give the human beings food. Groves play an important role in maintaining the food chain in the locality, harbouring a variety of forms ranging from micro-organisms in the humus to large plants and animals. The bird population in the groves help control the agricultural pests.

7. Medicinal plants, fast disappearing from the homesteads, are still preserved in several groves. They can be used for further propagation. A variety of seedlings of medicinal plants are available in various groves.

8. Plants like Kammatti, Cherikkotta etc. are raw materials used by traditional artisans among the villagers.

9. The groves are surviving gene pools. They are important in preserving the genetic diversity of the wild ancestors and allies of the cultivars and of indigenous fauna. Wild varieties of pepper, ginger, turmeric, cardamom, etc., are present in several groves like Kammadathkavu. Their seeds could be used for propagation as well as experimentation. Seeds and seedlings for social forestry may be selected from the groves.

10. Groves can promote eco-aesthetics. Groves have to be maintained as centres of social and cultural prospect as in the past. They will be useful as study centres for historical researchers.

\section{Necessity of conservation}

Sacred groves are to be considered as critical habitats offering resources directly as well as indirectly for the people of the locality. Strong taboos were helpful for their continued conservation. But how long will these beliefs help further their protection is the big question. Out of the 578 sacred groves, only 114 are recorded as remaining without quantitative degradation, and 105 as without qualitative degradation. Owing to human interference others have undergone degradation to various degrees. Conservation of sacred groves is an urgent necessity because the gene pool surviving in these groves might be lost forever if any further degradation is allowed to these fragile ecosystems.

In the changing social system it is not realistic to depend on taboos for the protection of sacred groves. The elder persons among the owners of certain groves will obviously showcase the importance of taboos in which they believe. It is time that the administration, environmentalist, academicians take some concrete steps in order to try to spread the importance of some basic ecological knowledge amongst the 
youths through seminars, symposia, group discussion etc. People must be made interested in acquiring knowledge on the biodiversity themes.

The fear of the elder generation is that the rituals may be renounced when ecological consciousness is promoted because many people may discard traditional activities as superstitions. Here an integrated approach is necessary. Rituals must persist as such because they maintain an institutional set-up giving a place for the kavus in the heart of the local residents. Ecological awareness must not mean keeping away from the traditions. Those who believe in traditions may protect the kavu due to their traditional beliefs. Others, who do not subscribe to such beliefs, could still protect the kavu for ecological reasons. Majority of people have vital interest in the preservation of the ecosystem, though many are not aware of it. It is essential that every effort should be made to make people conscious of the need for the conservation of our bio-resources.

\section{References}

Conserving the sacred: from species to landscapes, Nature and resources, UNESCO, 32. (1996).

Conserving the sacred: where do we stand? Proceedings of KFRI Workshop. (1997).

Part played by sacred groves in local environments. Project report submitted to centre for science and Environment, New Delhi. (1990).

Samooham, Charithram, Samskaram (historical essays in Malayalam), Calicut: Poorna Publications. (1981).

Uttara Keralathile Visudha Vanangal (Malayalam). Jeevarekha. (1995).

Balakrishnan K, Induchoodan N.C.: Plant diversity in sacred groves of Kerala, Evergreen No. 36, KFRI. (1996).

Freeman J.R.: Gods, Groves and the culture of Nature in Kerala. Modem Asian Studies 33 (2), Cambridge University Press. (1999).

Hughes J. D.: Sacred groves of the ancient Mediterranean area: early conservation of biological diversity. Proceedings of KFRI Workshop. (1997).

Hughes J. D., Subhaschandran. M. D. (1997): Sacred groves around the earth: an overview, Proceedings of KFRI Workshop.

Jayarajan. M.: Sacred Groves of North Malabar. Discussion Paper No. 92. Kerala Research Programme on Local Level Development, Centre for Development Studies. Trivandrum. (2004).

Ramachandran K. K. Mohanan C. N.: Studies on the sacred groves of Kerala, Final project report by Centre for Earth Science studies to Ministry of Environment and forests, Government of India. (1991).

Ramakrishnan P.S.: Conserving the sacred for biodiversity: the conception framework, Proceedings of KFRI Workshop. (1997). 
Subhash Chandran M. D., Hughes. J. D., Gadgil. M.: Sacred groves of the Western Ghats of India - Proceedings of KFRI Workshop. (1997).

Unnikrishnan E. : A Socio-Environmental study on Sacred Groves of North Kerala - report submitted to RANWA, Pune (1997). 